5. Новицкий В.В. Физиология и патофизиология эритроцита / В.В. Новицкий, Н.В. Рязанцева, Е.А. Степовая. - Томск: Из-воТГУ, 2004. - 202 с.

6. Козинец Г.И. Кровь: стабильность, консерватизм и память гемопоэза / Г.И. Козинец, В.В. Высоцкий, С.А. Луговская // Вестник службы крови России. - 2012. - № 2. - С. 20-27.

7. Murav'ev A.V., Tikhomirov I.A., Mikhaylov P.V., Muravieva A.A. Haemorheology and microcirculation: a textbook. Yaroslavl', 2010.

DOI https://doi.org/10.30525/978-9934-26-038-4-38

\title{
КЛІНІЧНІ ОСОБЛИВОСТІ АНОМАЛЬНИХ МАТКОВИХ КРОВОТЕЧ У ЖІНОК В СТАНІ ХРОНІЧНОГО СТРЕСУ
}

\author{
Федосюк К. В. \\ аспірант кафедри акушерства, гінекологї та репродуктології \\ Національний університет охорони здоров'я Украӥни \\ імені П. Л. Шупика \\ м. Київ, Україна
}

За даними науковців майже $30 \%$ жінок мали в своєму житті розлади менструального циклу різного характеру [3]. Такі порушення можуть проявлятись у вигляді нерегулярного циклу, зміні частоти менструальних кровотеч, різної тривалості та об'єму менструальних виділень. Аномальна маткова кровотеча (АМК) є частим розладом, який діагностується у жінок всіх вікових категорій - від підлітків, жінок репродуктивного віку та осіб в менопаузі. Вважають, що 10-30 \% жінок репродуктивного віку та біля 90 \% в перименопаузі зустрічались 3 даною патологією [2]. Причинами виникнення АМК можуть бути аденоміоз, фіброміома матки, поліпи порожнини матки, гіперплазія ендометрію, злоякісні пухлини та ін. $[4,5]$. Часто психологічні фактори $є$ підгрунтям перебігу даного процесу.

Метою нашого дослідження було встановити клінічні особливості аномальних маткових кровотеч у жінок в стані хронічного психоемоційного стресу.

Методи дослідження. У дослідження увійшло 100 жінок репродуктивного віку з АМК, які знаходились в стані хронічного стресового навантаження. Ці жінки становили основну групу. 30 жінок репродуктивного віку з АМК без факторів хронічного психоемоційного стресу становили групу порівняння. Діагноз АМК та її вид встановлювали на 
основі наказу № 353 МО3 України від 13.04.2016 [1]. Порівняння за однією ознакою виконували в програмі Statistica 6.0, використовуючи критерій $\chi^{2}$. Дані вважали достовірними при $\mathrm{p}<0,05$.

Результати дослідження. Нами не виявлено достовірної різниці у віці між хворими основної групи та групи порівняння. В обох групах переважали жінки віком до 40 років. За типом кровотеч гостра АМК зустрічалась частіше у пацієнток основної групи (38 (38,0 \%) хворих), що було в 1,9 рази більше, ніж в основній групі (6 (20,0 \%) осіб). Проте, кількість жінок, які мали хронічні АМК в основній групі (25 (25,0 \%) хворих) було достовірно менше в 2,9 рази, ніж в групі порівняння (22 $(73,3 \%)$ пацієнток; $\left.\left.\chi^{2}=50,84, \mathrm{p}<0,05\right)\right)$. А відсоток жінок з тяжкою АМК був в 5,2 рази більшим у жінок із хронічним стресом (37 (37,0\%) порівняно $з$ особами без стресу $\left(2(6,7 \%)\right.$ жінок; $\chi\left(^{2}=26,05, \mathrm{p}<0,05\right)$. Крім того, за останні два роки 46 (46,0 \%) пацієнток основної групи скаржились на нерегулярні менструації, 37 (37,0 \%) - на менструації, які тривають більше 8 днів, $6(6,0 \%)$ - епізоди аменореї. Тоді як в групі порівняння тільки по 6 осіб (20,0 \%) мали нерегулярні та тривалі менструації, а випадків аменореї не було. Крім того, у 5 (16,67 \%) хворих тривалість менструальної кровотечі становила менше, ніж два дні.

Висновки. Таким чином встановлено, що для жінок в стані хронічного стресового навантаження частота гострих та тяжких аномальних кровотеч $є$ достовірно більшою відносно осіб без стресового навантаження, у яких переважають хронічні аномальні кровотечі.

\section{Література:}

1. Наказ МОЗ України № 353 від 13.04.2016 «Уніфікований клінічний протокол первинної, вторинної (спеціалізованої) та третинної (високоспеціалізованої) медичної допомоги «Аномальні маткові кровотечі»«к. https://zakon.rada.gov.ua/rada/show/v0353282-16\#n20

2. Belcaro C., Scrimin F., Mangogna A., Galati E.F., Biffi S., Monasta L., Romano F., Ricci G. Comparison between Different Diagnostic Strategies in Low-Risk Reproductive Age and Pre-Menopausal Women Presenting Abnormal Uterine Bleeding. Diagnostics (Basel). 2020. Oct 30;10(11):884. doi: 10.3390/diagnostics10110884.

3. Kazemijaliseh H., Tehrani F.R., Behboudi-Gandevani S., Khalili D., Hosseinpanah F., Azizi F. A Population-Based Study of the Prevalence of Abnormal Uterine Bleeding and its Related Factors among Iranian Reproductive-Age Women: An Updated Data. Arch Iran Med. 2017. Sep. № 20(9). P. 558-563.

4. Matteson KA, Raker CA, Clark MA, Frick KD. Abnormal uterine bleeding, health status, and usual source of medical care: analyses using the 
Medical Expenditures Panel Survey. J Womens Health (Larchmt). 2013. Nov. № 22(11). P. 959-65. doi: 10.1089/jwh.2013.4288.

5. Yu L, Janga B, McAlister R, Jeffe DB, Sonn T. Disparities in Treatment Decisions for Abnormal Uterine Bleeding. J Womens Health (Larchmt). 2021 Feb 12. doi: 10.1089/jwh.2020.8800.

DOI https://doi.org/10.30525/978-9934-26-038-4-39

\title{
ANALYSIS OF CAUSES AND MORTALITY IN ACUTE PANCREATITIS
}

\author{
Formanchuk T. V. \\ Ph. D. in Medicine, Associate Professor, \\ Associate Professor at the Surgery Department № 2 with the course \\ "Fundamentals of Dentistry» \\ National Pirogov Memorial Medical University \\ Vinnytsya, Ukraine
}

Introduction. Acute pancreatitis remains an urgent problem of modern medicine. There is an increase in the incidence of acute pancreatitis worldwide. Despite current trends in multidisciplinary management of this pathology with the involvement of surgeons, gastroenterologists, resuscitators, endoscopists and other specialists, the mortality rate for this pathology remains high and ranges from $1 \%$ to $6,7 \%$. Since the 1970 s, there has been no decrease in mortality of acute pancreatitis $[1,2,3,4,5]$. Mortality of acute pancreatitis occurs from both early and late (septic) groups of complications.

The aim of the work. Analysis of the causes of mortality of acute pancreatitis.

Materials and methods. 48 fatal cases of the patients who were hospitalized in the Vinnytsya emergency hospital with a diagnosis of acute pancreatitis from 2015 to 2020 were analyzed. The diagnosis of acute pancreatitis was formed according to the Atlanta classification, 2012, in the presence of two of any three criteria: typical abdominal pain, serum lipase / amylase values in three times the upper limit of normal, typical signs in the imaging by ultrasound or computer tomography. Complications of acute pancreatitis were diagnosed on the basis of complaints, objective examination data, laboratory, endoscopic and histological examinations, ultrasound diagnostics and computed tomography data.

The youngest patient was 25 years old, the oldest -84 years old. There were 20 women $(41,7 \%)$ and 28 men $(58,3 \%)$. Among 48 fatal cases, 47 